\title{
SYÛRÂ DAN FENOMENA PEMILIHAN KEPALA DAERAH DI INDONESIA
}

\author{
Neneng Hasanah \\ Institut Pertanian Bogor (IPB) \\ Jl. Raya Darmaga, Kampus IPB, Darmaga, Bogor \\ E-mail: hasanahneneng75@yahoo.co.id
}

\begin{abstract}
Shura and the Phenomenon of Local Elections in Indonesia. Shura and the elections are social institutions in the political arena in Indonesia. In Islam, choosing a leader is a necessity. Direct election is a mechanism that has been exemplified by the Companions of the Prophet, for instance, when choosing Abu Bakr R.A. as the leader of the Muslims after the Prophet passed away. There was no will for this election. Based on divine guidance and the instinct of the Companions about Abu Bakr's personality, Muslims did shura and directly selected Abu Bakr to be the first Caliph.
\end{abstract}

Keywords: shûrâ, elections, social institutions of Islam

\begin{abstract}
Abstraksi: Syûrâ dan Fenomena Pemilihan Kepala Daerah di Indonesia. Syûrâ dan Pilkada merupakan pranata sosial di bidang politik yang sudah membumi di Indonesia. Dalam Islam memilih pemimpin adalah sebuah keniscayaan. Pemilihan secara langsung merupakan mekanisme yang sudah dicontohkan oleh para Sahabat Nabi Saw., seperti ketika memilih Abu Bakr R.a. sebagai pemimpin kaum Muslimin setelah Rasulullah Saw. wafat. Tidak ada wasiat apapun terkait penunjukan pengganti. Kemudian atas petunjuk ilahi yang juga dilandasi naluri para Sahabat terhadap sosok dan kepribadian Abu Bakr Ra., maka kaum Muslimin melakukan syûrâ dan secara aklamasi dan memilih langsung Abu Bakr menjadi Khalifah pertama.
\end{abstract}

Kata Kunci: Syûrâ, Pilkada, pranata sosial Islam

\section{Pendahuluan}

Islam merupakan agama (al-dîn) yang luhur dan mulia. Syariatnya bertujuan untuk memuliakan dan memosisikan umat-Nya sebagai hamba yang memiliki 'izzah dan harga diri di hadapan yang lainnya. Tak terkecuali persoalan yang berkenaan dengan syûrâ (musyawarah). Syûrâ merupakan perintah-Nya agar kehidupan manusia menjadi tertata, teratur, dan memiliki pranata sosial, serta lingkungan kehidupan yang disiplin, benar, dan terkendali dalam urusan dengan makhluk sesamanya.

Syûrâ adalah metode yang berhubungan erat dengan akidah dan syariah. Dengan syûrâ solusi untuk mendapatkan hasil yang terbaik sekalipun hasilnya terkadang tidak sesuai dengan yang diinginkan. Tidak ada yang menyesali karena merupakan hasil kesepakatan bersama. Kesalahan yang dilakukan setelah musyawarah tidak sebesar kesalahan yang dilakukan tanpa musyawarah. Kebenaran yang diraih sendirian, tidak sebaik kebenaran yang diraih bersama, dalam literatur

Naskah diterima: 2 Oktober 2015; Direvisi: 10 Juni 2016; Disetujui untuk diterbitkan: 16 Juni 2016.
Islam dinyatakan, ما خاب من استخارولاندم من استشار (“Tidak akan rugi orang yang melakukan istikharah dan tidak akan menyesal orang yang bermusyawarah"). Hal ini juga sejalan dengan perintah Allah dalam Alquran surah Âli 'Imrân ayat 159.

Pada ayat tersebut digambarkan pentingnya bermusyawarah dan sikap seseorang pasca bermusyawarah. Ayat ini diakhiri dengan kata-kata "Allah menyukai orang-orang yang bertawakal kepada-Nya". Maksudnya, secara eksplisit, bertawakal merupakan tahapan perintah ketiga pasca melakukan syûrâ. Adapun sikap yang dilakukan ketika berlangsung musyawarah adalah sebagai berikut: Pertama, sikap lemah lembut. Seseorang yang melakukan musyawarah, apalagi sebagai pemimpin, harus menghindari tutur kata yang kasar serta sikap keras kepala, karena jika tidak, mitra musyawarah akan bertebaran pergi. Kedua, memberi maaf dan membuka lembaran baru. Ini diperlukan karena tiada musyawarah tanpa pihak lain, sedangkan kecerahan pikiran hanya hadir bersamaan dengan sirnanya kekeruhan hati. Ketiga, permohonan ampunan ilahi merupakan kunci kesuksesan bermusyawarah. 
Jadi, Allah Swt. memerintahkan untuk bermusyawarah dan setelah mufakat kemudian dipersilahkan untuk memantapkan dan meneguhkan hati kemudian hasilnya diserahkan kepada Allah Swt. Dengan syûrâ tidak ada orang yang egois, menyepelekan pendapat yang lain, dan menyalahkannya. Hal ini sudah dicontohkan Rasulullah Saw., para Sahabat, dan al-salaf al-shâlih

Demikian pula dalam fenomena pemilihan kepala daerah yang ada di Indonesia. Sistem demokrasi-yang digunakan dalam pilkada dengan cara memilih langsung atau tidak langsung seorang pemimpin-merupakan pranata sosial yang sudah melekat pada Pemerintahan negara dan bangsa ini. Sejak pemerintahan Presiden Susilo Bambang Yudhoyono, tepatnya Juni tahun 2005, pilkada langsung menjadi fenomena politik yang tak terbantahkan.

Pilkada merupakan proses demokrasi yang melibatkan partisipasi rakyat, yang hasil akhirnya juga harus ditanggung oleh rakyat yang memilihnya. Seperti jika terjadi masalah dalam kepemimpinannya, misalnya melakukan korupsi, kolusi dan nepotisme (KKN) atau dengan kata lain bahwa tidak dapat menjamin dengan pilkada langsung dapat mewujudkan rakyat hidup makmur dan sejahtera.

Dalam kaitan ini, penulis akan mengupas mengenai syûrâ dan fenomen pemilihan kepala daerah di Indonesia, baik secara sosio-historis, substansi, dan kultur masyarakat di Indonesia.

\section{Syûrâ dalam Islam}

Syûrâ terambil dari kata sya, wa, ra, yang pada mulanya bermakna mengambil madu dari sarang lebah ${ }^{1}$. Makna ini kemudian berkembang, sehingga mencakup segala sesuatu yang dapat diambil atau dikeluarkan dari yang lain (termasuk pendapat). Selanjutnya al-Ishfahanî menyatakan bahwa musyawarah dapat juga berarti mengatakan atau mengajukan sesuatu. Kata syûrâ bermakna mengambil dan mengeluarkan pendapat yang terbaik dengan memperhadapkan satu pendapat dengan pendapat yang lain. Kemudian dia mendefinisikan syûrâ sebagai proses mengemukakan pendapat dengan saling merevisi antara peserta syûrâ.

Kata ini terambil dari kalimat syirtu al-'asal yang bermakna saya mengeluarkan madu (dari wadahnya). ${ }^{2}$ Ini berarti mempersamakan pendapat yang terbaik dengan madu, dan bermusyawarah adalah upaya meraih

1 Ahmad Warson Munawwir, Al-Munawwir: Kamus ArabIndonesia, (Surabaya: Pustaka Progreesif, 1997), h. 750.

${ }^{2}$ Al-Râghib al-Ishfahanî, Mufradât Alfâzh al-Qurân, (Bayirût: alMaktabah al-Assrya, t.th), h. 288-289. madu itu dimanapun dia ditemukan, atau dengan kata lain, pendapat siapa pun yang dinilai benar tanpa mempertimbangkan siapa yang menyampaikannya, maka pendapat itulah yang akan diambil setelah dimusyawarahkan ${ }^{3}$.

Dari beberapa definisi di atas tentang Syûrâ, penulis berpendapat bahwa Syûrâ (musyawarah) sesuai dengan makna asal katanya mengeluarkan madu yang berarti obat tapi manis. Syûrâ berarti mencari solusi dari suatu masalah agar mendapatkan yang terbaik dengan cara musyawarah (meminta dan mendengar) pendapat orang lain, kemudian saling mengevaluasi dan merevisi pendapatnya kembali sampai mendapatkan kesepakatan bersama.

Bila dicermati, syûrâ menjadi menarik untuk dikaji lebih dalam. Dari sisi historis, substansi, dan kultur masyarakat, ia merupakan sebuah pranata sosial yang mayoritas masyarakat sudah menjalankannya. Sekalipun terkadang hasil musyawarah pun tidak selamanya benar dan tepat, sebagaimana yang pernah terjadi pada Rasulullah Saw. dan para Sahabat di perang Uhud. Sekalipun demikian, musyawarah itu lebih baik dari pada pendapat sendiri.

Sebagai pranata sosial yang sudah menjadi budaya bangsa, dan umat Islam khususnya, syûrâ untuk konteks keindonesiaan-yang mayoritas penduduknya adalah Muslim-menempati posisiyangsangat tinggi. Misalkan dalam Negara Republik Indonesia, ia sudah diwadahi dengan nama MPR (tempat bermusyawarahnya para wakil rakyat) yang dulu kedudukan dan posisinya adalah Lembaga Tertinggi Negara, yang salah satu tugasnya mengangkat dan memberhentikan Presiden. Kemudian setelah Era Reformasi ini menjadi sejajar kedudukannya dengan anggota DPR. Selain di Pemerintahan, banyak pula partai dan institusi lain yang menggunakan istilah dengan dewan syûrâ, dan bahkan Pancasila yang menjadi Dasar Negara Indonesia pada sila keempat mencantumkan kata-kata permusyawaratan, yang menunjukkan akan pentingnya musyawarah bagi bangsa ini.

Bila mencermati asal kata Syûrâ secara etimologi yang sudah disebutkan di atas, yaitu menghasilkan sesuatu yang manis (bermanfaat). Selanjutnya dapat dilihat pula implementasi syûrâ dan ruang lingkupnya, yaitu secara individu, keluarga, dan masyarakat sampai ke Negara dengan merujuk pada syariat Islam. Contoh dalam kehidupan individu adalah seperti dalam kisah para Sahabat Nabi Saw., mereka sering meminta pendapat

\footnotetext{
${ }^{3}$ M. Quraish Shihab, Wawasan al-Qur'an: Tafsir Tematik atas Berbagai Persoalan Umat, (Jakarta: Mizan, 2007), h. 617.
} 
Rasulullah Saw. dalam masalah-masalah yang bersifat personal. Sebagai contoh adalah tindakan shahabiyah Fathimah binti Qays yang meminta pendapat kepada Nabi Saw. ketika Mu'awiyah dan Abu Jahm berkeinginan untuk melamarnya [H.r. Muslim: 1480].

Ada beberapa ayat yang akar katanya menunjukkan tentang syûrâ (musyawarah) dan menjadi dalil perintah syûrâ, antara lain:

a. Q.s. al-Baqarah [2]: 233

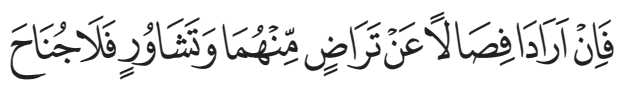

Apabila keduanya ingin menyapih (sebelum dua tahun) dengan kerelaan keduanya dan permusyawaratan, maka tidak ada dosa atas keduanya.

Ayat ini berkenaan dengan syûrâ dalam kehidupan berkeluarga, membicarakan bagaimana seharusnya hubungan suami istri saat mengambil keputusan yang berkaitan dengan rumah tangga dan anak-anaknya, seperti: menyapih anak atau memberikan susuan kepada orang lain (perempuan lain yang memiliki akhlak mulia), "jika istrinya lemah". Pada ayat di atas, Alquran memberi petunjuk agar persoalan itu dan (persoalanpersoalan rumah tangga lainnya) dimusyawarahkan antar suami istri. ${ }^{4}$

Ayat di atas menginspirasikan kepada kita bahwa betapa Islam sangat peduli terhadap isu apapun yang akan dialami oleh umatnya, terlebih masalah keluarga yang merupakan miniatur dari sebuah masyarakat. Dalam kehidupan berkeluarga, Islam mengajak kita untuk membina mahligai rumah tangga atas dasar musyawarah dan saling rida. Oleh karenanya, nas-nas syariat menolak adanya paksaaan seorang ayah untuk menikahkan putrinya tanpa meminta pendapatnya, walaupun putrinya itu masih gadis. Sebaliknya, Islam mewajibkan-sebagaimana disebutkan dalam banyak Hadis Nabi-agar anak gadis itu dimintai izin. Jika ia merasa malu, maka persetujuannya adalah diamnya 5 .

Syûrâ yang merupakan perintah Ilahi. Bila dilihat pada fenomena yang terjadi di masyarakat, banyak keluarga yang sering mengabaikannya, dengan alasan sibuk, tidak ada waktu atau intensitas yang berkurang untuk bertemu antara suami istri, jarak yang memisahkan, komunikasi yang tidak lancar, dan sebagainya. Maka akhirnya timbullah perselisihan berkepanjangan yang berujung

${ }^{4}$ Muhammad 'Alî al-Shâbûnî, Shafwah al-Tafâsir, (Bayrût: Dâr alQalam), Juz I, h. 151. Lihat pula pada Yûsuf al-Qarâdhawî, Malamih al-Mujtama'al-Muslim", edisi terjemah, Masyarakat Berbasis Syariat Islam, (Solo: Era Adicitra Intermedia, 2013), Cet. II, h. 188.

5 Yûsuf al-Qarâdhawî, "Malâmih al-Mujtama' al-Muslim", edisi terjemah, Masyarakat Berbasis Syariat Islam, h. 186. Lihat pula dalam Abdurrahman al-Jâzirî, Al-iqh 'ala al-Madzahib al-arba’ah” (Beirut: Daar al-Fikr), 32 pada perceraian yang tidak diinginkan oleh kedua belah pihak, tapi diinginkan oleh musuhnya, yaitu "al-syaythân al-rajîm".

Kembali kepada ayat di atas, sekalipun dalam hal menyusui adalah kewajiban istri dan hak anak, tapi suami tetap bertanggung jawab dan menjadi kewajibannya untuk menjamin keberlangsungan hidup keduanya, sehingga wajib dimusyawarahkan agar tidak menyesal di kemudian hari. Misalnya, istri yang tidak bisa menyusui karena lemah, baik kondisi fisiknya atau lemah karena faktor lain yaitu karena lelah (sibuk) menjadi perempuan karier, tentu hal ini harus dimusyawarahkan dalam penyusuan dan penyapihannya secara benar agar hasilnya menjadi manis dan tidak mengorbankan anak sebagai tanggungjawab kedua orang tuanya.

b. Q.s. Âli ‘Imrân [3]: 159

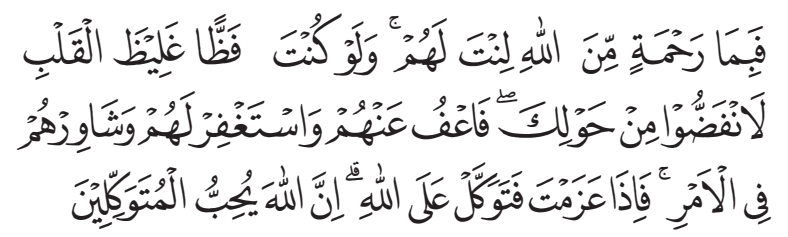

Maka disebabkan rahmat dari Allah-lah kamu berlaku lemah lembut terhadap mereka. Sekiranya kamu bersikap keras lagi berhati kasar, tentulah mereka menjauhkan diri dari sekelilingmu. Karena itu maafkanlah mereka, mohonkanlah ampun bagi mereka, dan bermusyawarahlah dengan mereka dalam urusan itu. Kemudian apabila kamu telah membulatkan tekad, maka bertawakallah kepada Allah. Sesungguhnya Allah menyukai orang-orang yang bertawakal kepada-Nya.

Ayat ini dari segi redaksional ditujukan kepada Nabi Muhammad Saw., sesuai dengan kata perintahnya yang tunggal, yaitu agar Nabi memusyawarahkan persoalanpersoalan tertentu dengan para Sahabat atau anggota masyarakatnya. Tetapi para mufasir sepakat bahwa ketika ayat itu ditujukan kepada Nabi Saw. berarti ditujukan pula untuk umatnya. Ayat ini merupakan petunjuk bagi setiap Muslim, khususnya setiap pemimpin agar senantiasa bermusyawarah dengan anggota-anggotanya. Logikanya, Nabi saja yang sudah dijamin tidak melakukan dosa dan kesalahan (máshûm) diperintahkan untuk melakukan musyawarah apalagi manusia selain beliau.

Kemudian pada ayat di atas disebutkan tiga sikap yang secara berurutan diperintahkan kepada Nabi Muhammad Saw. untuk melakukan sebelum datangnya perintah bermusyawarah. Sikap-sikap tersebut adalah sebagaimana terangkum dalam ayat diatas. Pertama, sikap lemah lembut. Seseorang yang melakukan musyawarah, apalagi sebagai pemimpin harus menghindari tutur kata yang kasar serta sikap keras kepala, karena jika tidak, mitra musyawarah akan bertebaran pergi (ولو كنت فظا غليظ القلب لانفضوا من حولك). 
Kedua, memberi maaf dan membuka lembaran baru. Dalam ayat di atas disebutkan, "Fa'fu 'anhum (maafkanlah mereka). Quraish Shihab mengartikan kata "maaf" secara harfiyah dengan menghapus. Memafkan adalah menghapus bekas luka di hati akibat perlakuan pihak lain yang dinilai tidak wajar. Ini perlu, karena tiada musyawarah tanpa adanya pihak lain, sedangkan kecerahan pikiran hanya hadir bersamaan dengan sirnanya kekeruhan hati ${ }^{6}$.

Ketiga, yang harus mengiringi musyawarah adalah memintakan ampunan Allah bagi mereka (para anggota musyawarah). Dan yang terakhir sebagaimana ayat di atas adalah bertawakkal kepada Allah atas apa yang sudah diusahakan/ dimusyawarahkan sebagai bentuk kepasrahan bahwa hasil akhirnya diserahkan kepada Allah SWT Yang Maha Mengetahui baik dan buruk bagi hamba-Nya ${ }^{7}$.

c. Q.s. al-Syûrâ [42]: 38

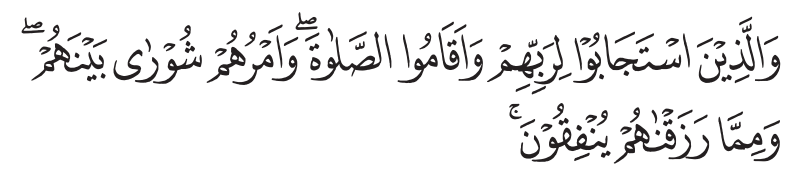

Dan (bagi) orang-orang yang menerima (mematuhi) seruan Tuhannya dan mendirikan salat, sedang urusan mereka (diputuskan) dengan musyawarat antara mereka; dan mereka menafkahkan sebagian dari rezki yang Kami berikan kepada mereka”.

Ayat ketiga ini turun sebagai pujian kepada kelompok Muslim Madinah (Anshâr) yang bersedia membela Nabi Saw. dan menyepakati hal tersebut melalui musyawarah yang mereka laksanakan di rumah Abû 'Ayyûb al-Anshârî. Namun demikian ayat ini juga berlaku umum, mencakup setiap kelompok yang melakukan musyawarah ${ }^{8}$. Yûsuf al-Qarâdhawî berpendapat bahwa ayat di atas adalah ayat tentang perintah syûrâ, ia (syûrâ) dimasukkan kedalam salah satu sifat orang yang beriman, disertai dengan sifat-sifat asasi yang lainnya. Di mana keislaman dan keimanan seseorang tidak sempurna kecuali dengan sifat-sifat itu, di antaranya: menyambut seruan Allah, mendirikan salat, dan menginfakkan apa yang diberikan Allah kepadanya. Dan dalam ayat tersebut Allah berfirman,

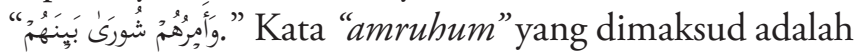
urusan mereka, urusan yang bersifat umum dan sebagai kepentingan bersama. Itulah yang diperintahkan Allah kepada rasul-Nya agar bermusyawarah. ${ }^{9}$

\footnotetext{
${ }^{6}$ M. Quraish Shihab, Wawasan al-Qur'an: Tafsir Tematik atas Berbagai Persoalan Umat, h. 623-624.

${ }^{7}$ M. Quraish Shihab, Wawasan al-Qur'an dan lihat pula pada Muhammad 'Alî al-Shâbûnî "Mukhtashar Tafsîr Ibn Katsir," (Bayrût: Dâr al-Fikr), h. 331-332.

${ }^{8}$ M. Quraish Shihab, Wawasan al-Qur'an, h. 619.

${ }^{9}$ Yusuf al-Qaradhawi, Masyarakat Berbasis Syariat Islam, h. 189.
}

Dalam pendapatnya, Taufiq Muhammad al-Syâwî menyatakan bahwa ayat di atas memberikan isyarat bahwa kegotongroyongan dalam infak dan kerjasama dalam harta berhubungan dengan kerjasama dalam tukar pikiran. Kedua-duanya bagaikan saudara kembar dari kebebasan berpendapat.Keterkaitan Syûrâ dengan jamin-menjamin, solidaritas sosial, kemerdekaan manusia, dan hak-hak asasinya juga menjadikan Sŷ̂râ sebagai prinsip sosial yang universal, bukan sekedar prinsip politik ${ }^{10}$. Dalam pendapatnya pula al-Syâwî menyatakan bahwa masyarakat yang mengabaikan syûrâ dapat dianggap sebagai masyarakat yang mengabaikan salah satu perintah Allah Swt. Dia mengutip dari pendapat al-Jasshâsh dalam kitabnya, A $\underline{h} k \hat{a} m$ al-Qur'ân, bahwa syûrâ mempunyai martabat sesudah ibadah terpenting, yaitu salat. ${ }^{11}$

Kesimpulan dari ayat ketiga di atas adalah, urgensi syûrâ menjadikannya disejajarkan dengan perintah salat, sehingga ketika kita mengabaikan atau bahkan meninggalkannya berarti sama dengan mengabaikan dan meninggalkan perintah salat. Karena iman dan amal shaleh harus selalu terintegrasi sebagaimana Allah SWT.selalu mengiringi kata iman dengan amal shaleh dalam setiap penyebutannya dalam ayat al-Qur'an. Sebagai contoh ayat yang populer tentang hal itu adalah Q.s. al-'Ashr: 2-3:

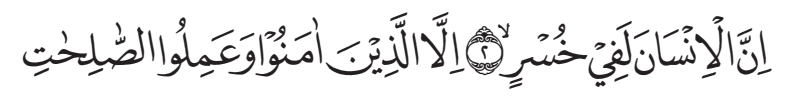

...Sesungguhnya semua manusia itu dalam keadaan merugi, kecuali yang beriman dan beramal shaleh...

Berarti syûrâ adalah termasuk amal salih yang harus menjadi habit bagi manusia, khususnya Muslim yang beriman. Oleh karena itu, kaitannya syûrâ dengan Pilkada adalah sebuah keniscayaan dan keterkaitan yang sangat erat, bila dikiaskan dengan imam salat, maka sangat erat antara imam sebagai pemimpin Negara/daerah dengan seorang imam/pemimpin salat. Ketika seorang imam salat harus memiliki criteria sebagai berikut: baligh, usia lebih tua, fasih bacaan Alquraannya, lebih banyak hafalannya, lebih mumpuni disiplin ilmunya, dan sebagainya. Demikian dengan, pemimpin bagi sebuah Negara/daerah, musyawarah dalam Pilkada untuk menentukan seorang pemimpin merupakan sebuah keniscayaan.

Adapun dalil 'amaliyah dan qawliyah dari Sunah Nabi tentang syûrâ adalah antara lain: Pertama, Abû Hurayrah berkata, "Saya tidak pernah melihat seorang

\footnotetext{
${ }^{10}$ Tawfiq Muhammad al-Syâwî, Figh al-Syûrâ wa al-Istisyarah, edisi terjemah: Demokrasi atau Syura, Penerjemah, Djamaluddin Z.S., (Jakarta: Gema Insani, 2013), h. 23.

${ }^{11}$ Tawfiq Muhammad al-Syâwî, Fiqh al-Syûrâ wa al-Istisyarah, h. 24.
} 
yang paling banyak melakukan musyawarah dengan rekan-rekannya melebihi Rasulullah Saw." ${ }^{2}$ Kedua, Rasulullah Saw. Bersabda, "Tidaklah bermusyawarah suatu kaum melainkan mereka akan ditunjuki pada perkara mereka yang paling benar." (H.r. al-Bukhârî). Ketiga, Rasulullah Saw. Bersabda, "Siapa saja yang memisahkan diri dari jemaah, dia mati jahiliyah.” (H.r. Imam Abû Dâwud)

Dengan demikian, sesungguhnya sumber hukum yaitu Alquran dan Sunah-sunah Nabi Saw. baik secara qawliyah dan filiyah telah memerintahkan dan mencontohkan kepada umatnya untuk selalu bermusyawarah dalam setiap urusan, agar tidak menyesal di kemudian hari sekalipun hasilnya tidak selalu tepat, karena dengan syûrâ jaminan keberlangsungan agenda permasalahan akan tertangani dengan baik. Syûrâ merupakan jaminan ilahiyah, karena ia merupakan perintah ilahi.

Beberapa masalah musyawarah menurut para ulama, sebagaimana dikutip dari Wawasan al-Qur'an, karya M. Quraish Shihab, bahwa dalam bermusyawarah ada hal-hal yang harus diperhatikan, antara lain: (a) Orang yang diminta bermusyawarah; (b) Dalam hal-hal apa saja musyawarah dilaksanakan; (c) Dengan siapa sebaiknya musyawarah dilakukan; (d) Adapun orangorang yang diminta bermusyawarah adalah mereka yang berkesinggungan dengan masalah yang sedang dihadapi. Sebagaimana dalam redaksi surah Ali 'Imran ayat 159, sekalipun redaksinya dengan kata perintah tunggal yang tujuannya hanya untuk Rasulullah Saw. Tapi bukan berarti manusia selain Rasul Saw. tidak diperintahkan bermusyawarah, bahkan sebaliknya. Dalam ayat 159 di atas, turun setelah perang Uhud, di mana Rasululullah mendapatkan kekalahan pada waktu perang tersebut, padahal lokasi peperangan ditentukan dari hasil musyawarah.

Sebelum perang Uhud, Rasulullah Saw. meminta pendapat kepada para Sahabat untuk menghadapi musuh yang sedang dalam perjalanan dari Mekah ke Madinah, apakah Rasul Saw. beserta pasukan tentara keluar kota Madinah atau tetap bertahan di Madinah. Dalam musyawarah itu, mereka dari kaum muda yang masih semangat dengan darah mudanya, mengajak agar Rasul Saw. bersama kaum Muslimin "keluar" menghadapi musuh agar tidak dianggap pengecut. Pendapat mereka ini memperoleh dukungan dari banyak kalangan sehingga Nabi Saw. menyetujuinya. Tetapi peperangan berakhir dengan kekalahan dan banyak Sahabat yang gugur termasuk pamanda Rasul

\footnotetext{
${ }^{12}$ Ibn Hisyâm, Sirah Ibn Hisyam, dikutip dari Tawfiq Muhammad al-Syâwî, h. 52.
}

Saw. yaitu Hamzah ra. dan yang lainnya berjumlah tidak kurang dari tujuh puluh Sahabat yang menjadi syuhada perang Uhud. ${ }^{13}$

Konteks turunnya ayat ini, serta kondisi psikologis yang dialami Rasulullah Saw. dan para Sahabat setelah turunnya ayat ini, sangat perlu digarisbawahi yaitu bagaimana pandangan Alquran tentang musyawarah. Ayat ini seakan-akan berpesan kepada Nabi Saw. bahwa musyawarah tetap harus dipertahankan dan dilanjutkan walaupun terbukti pendapat yang mereka putuskan keliru. Kesalahan mayoritas lebih dapat ditoleransi dan menjadi tanggung jawab bersama, dibandingkan dengan kesalahan seseorang meskipun diakui kejituan pendapatnya sekalipun. ${ }^{14}$

\section{Urgensi Syûrâ}

Urgensi dan faidah syûrâ banyak diterangkan oleh para ulama, di antaranya imam Fakhr al-Dîn al-Râzî dalam Mafâtih al-Ghayb IX. Secara ringkas beliau menyebutkan bahwa syûrâ memiliki beberapa faidah. Pertama, musyawarah yang dilakukan Nabi Saw. dengan para Sahabatnya menunjukkan ketinggian derajat mereka (di hadapan Nabi) dan juga hal ini membuktikan betapa cintanya mereka kepada beliau dan kerelaan mereka dalam menaati beliau. Jika beliau tidak mengajak mereka bermusyawarah, tentulah hal ini merupakan bentuk penghinaan kepada mereka.

Kedua, musyawarah perlu diadakan karena bisa saja terlintas dalam benak seseorang pendapat yang mengandung kemaslahatan dan tidak terpikir oleh Waliy al-Amr (penguasa). Al- $\underline{\text { Hasan }}$ pernah mengatakan:

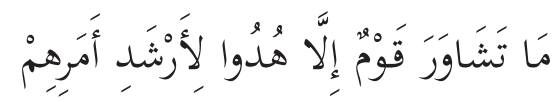

Setiap kaum yang bermusyawarah, niscaya akan dibimbing sehingga mampu melaksanakan keputusan yang terbaik dalam permasalahan mereka. (Al-Adab, karya Ibn Abî Syaybah 1/149).

Kedua, al- $\underline{H} a s a n$ dan Sufyan ibn 'Uyainah mengatakan, "Sesungguhnya Nabi diperintahkan untuk bermusyawarah agar bisa dijadikan teladan bagi yang lain dan agar menjadi Sunah (kebiasaan) bagi umatnya”.

Ketiga, syûrâ memberitahukan kepada Rasulullah Saw. dan juga para penguasa setelah beliau mengenai kadar akal dan pemahaman orang-orang yang mendampinginya, serta untuk mengetahui seberapa besar kecintaan dan keikhlasan mereka dalam menaati beliau.

${ }^{13}$ Ibnu Hisyam "Sirah Nabawiyah Ibnu Hisyam" penj. Fadhli Bahri (Jakarta: Darul Falah), 2005, 25-26. Lihat pula dalam : M. Dhiauddin Rais “ al-Nadzariyyat al-Siayasah al-Islamiyyah” trjmh :" Teori Politik Islam” Penj. Abd Hayyie al-Kattani dkk. (Jakarta: Gema Insani Press), 273

${ }^{14}$ M. Quraish Shihab, 626 lihat pula as-Syawi, 37 
Dengan demikian, akan tampak baginya tingkatan mereka dalam keutamaan. ${ }^{15}$

Keempat, syûrâ mengandung nilai penghormatan kepada orang-orang yang diajak bermusyawarah dan diminta pandangan, menggodok permasalahan yang diajukan dengan menampung berbagai pandangan dan ide-ide yang ada.

Kelima, menyatukan langkah dan memilih pandangan yang paling tepat. Abû Dâwud meriwayatkan dari Abû Hurayrah Ra., "Apabila seseorang dimintai pandangan, maka posisinya adalah orang yang dipercaya." Maksudnya, ia tidak boleh mengkhianati orang yang meminta pandangan kepadanya dengan menyembunyikan apa yang baik untuknya. ${ }^{16}$

\section{Perbedaan Syûrâ dan Demokrasi}

Alquran dan Sunah menetapkan beberapa prinsip pokok berkaitan dengan kehidupan politik, seperti al-syûrâ, keadilan, tanggung jawab, kepastian hukum, jaminan hak-hak manusia, dan lainnya yang semuanya ada kaitannya dengan syûrâ dan demokrasi.

Menurut al-Syâwi, sistem demokrasi dan syûrâ mempunyai perbedaan dan kesamaan. Di antara perbedaannya adalah syûrâ secara komperhensif merupakan sistem Islam. Ini adalah perintah ilahi yang kebenarannya bersifat mutlak dan melampaui ruang lingkup sistem pemerintahan dan konstitusi Negara. Ia mengandung prinsip-prinsip agama yaitu mencakup prinsip akhlak, pendidikan, dan bimbingan. Berbeda dengan demokrasi yang bersumber dari politik (Barat) ia bersifat nisbi (relatif). Sebagai sistem politik yang mencakup kaidah-kaidah sistem pemerintahan dan negara dan pemerintah dengan umat beserta individunya. Ia tidak mementingkan sisi akhlak, dalam anggapannya bahwa akhlak terpisah dari demokrasi. ${ }^{17}$

Adapun al-Qarâdhawî dan Dhiauddin Rais, sedikit berbeda dengan al-Syâwî dalam konteks definisi dan terminologi demokrasi. Menurut Dhiauddin Rais, "Jika demokrasi yang didefinisikan oleh Lincolen, yaitu "pemerintahan rakyat, melalui rakyat, dan untuk kepentingan rakyat". Maka tidak diragukan lagi telah tercakup dalam pemerintahan Islam. ${ }^{18} \mathrm{Hal}$ ini didukung oleh al-Qarâdhawî, "Bahwa jika demokrasi yang dimaksud adalah rakyat memilih orang yang akan

\footnotetext{
${ }^{15} \mathrm{http} / /$ muslim.or.id/manhaj/syura-dalam-pandangan-islam-dandemokrasi.html. diunduh pukul 6.45WIB, Rabu 18/03/15

${ }^{16}$ Wahbah al-Zuhaylî, Tafsîr al-Munîr: Aqîdah, Syarîah, Manhaj, Penj. Abdul Hayyie al-Kattani, dkk, (Jakarta: Gema Insani, 2013), h. 477-478.

${ }^{17}$ Tawfiq Muhammad al-Syâwi, Demorasi atau Syura, h. 72-73.

${ }^{18}$ M. Dhiauddin Rais, Teori Politik Islam, h. 307.
}

memerintah dan menata persoalan mereka, tidak boleh dipaksakan kepada mereka penguasa yang tidak mereka sukai atau rezim yang mereka benci, mereka diberi hak untuk mengoreksi penguasa jika keliru, diberi hak untuk mencabut dan menggantinya bila menyimpang, mereka tidak boleh digiring dengan paksa untuk mengikuti berbagai sistem ekonomi, sosial dan politik yang tidak mereka kenal dan tidak mereka sukai. Bila sebagian dari mereka menolak, maka mereka tidak boleh dipaksa, dianiaya atau dibunuh. ${ }^{19}$

Bila diperhatikan dari pendapat para ilmuan di atas, penulis menyimpulkan bahwa secara hakiki mereka tidak berbeda tentang sistem Syûrâ dan demokrasi, hanya saja tolok ukur al-Syawi mendefinisikannya dari konteks politik Barat dan yang terjadi pada sistem demokrasi saat ini. Sedangkan al-Qarâdhawî dan Rais melihat dari sisi demokrasi yang islami dan idealnya, sehingga mereka berdua menyatakan: "Tidaklah benar orang yang menolak sistem demokrasi jika ia tidak memahaminya secara utuh". Artinya orang yang menolak sistem demokrasi berarti mereka hanya memandang bahwa sistem tersebut dari Barat dan harus ditolak, karena Barat adalah kafir berarti sistemnya adalah Thagut dan harus ditolak, mereka yang demikian adalah putus asa dari rahmat Allah. Kemudian bagaimana dengan system demokrasi yang digunakan di Indonesia?Menurut penulis, system demokrasi yang ada di Indonesia sudah menyimpang dari ketentuan Islam.Mengapa demikian? Definisi dari rakyat, oleh rakyat dan untuk rakyat....hanya sebatas dari rakyat dan oleh rakyat saja...yaitu pemimpinnya dari rakyat kemudian dipilih oleh rakyat, tetapi ketika sudah terpilih menjadi pemimpin dan pejabat... rakyat ditinggalkan dan tidak merasakan kenikmatan dan kebahagiaan yang mereka rasakan..bahkan yang menikmati hasil dari kepemimpinannya adalah segolongan dan partai pendukungnya saja, sementara rakyat yang tidak memahami perpolitikan hanya gigit jari dengan merasakan kesengsaraan yang tak kunjung akhir... Wallahu a'lamu

\section{Fenomena Pilkada di Indonesia}

Pemilihan umum kepala daerah dan wakil kepala daerah yang selanjutnya disebut Pilkada adalah, pemilu untuk memilih kepala daerah dan wakil kepala daerah secara langsung dalam bingkai Negara Kesatuan Republik Indonesia, yaitu oleh penduduk daerah setempat yang memenuhi syarat berdasarkan Pancasila dan UUD 1945. Indonesia yang notabene penduduk-

\footnotetext{
${ }^{19}$ Al-Qaradhawi "Fiqih Negara”, 224-225
} 
nya Muslim, maka kriteria Pilkada selayaknya dan sepantasnya disesuaikan dengan aturan yang ada yaitu sesuai dengan UUD ' 45 dan dasar Negara Indonesia yaitu Pancasila. Pada dasarnya keduanya (UUD’45 dan Pancasila) sudah merepresentasikan Islam dalam bingkai bangsa Indonesia. Seperti dalam pembukaan UUD'45 “Bahwa sesungguhnya kemerdekaan itu ialah hak segala bangsa dan oleh sebab itu, maka penjajahan diatas dunia harus dihapuskan karena tidak sesuai dengan perikemanusiaan dan perikeadilan. ${ }^{20}$ " dan isi kandungan Pancasila dari mulai sila pertama sampai kelima, khususnya dalam masalah Pilkada ada dalam sila ketiga, yaitu "Persatuan Indonesia". Dalam pembukan UUD'45 dan Pancasila sila ketiga, merupakan aturan Islam yang diejawantahkan dalam kedua sumber aturan di Indonesia. Sebenarnya regulasi yang ada mengacu kepada kedua sumber tersebut, jika dijalankan dengan baik dan benar, maka tidak ada lagi unsur-unsur yang akan memanipulasi soal Pilkada, seperti, obral janji dan money politik. Karena hal seperti itu hanya akan memecah ummat atau bangsa Indonesia. Dalam Islam dijelaskan dalam firman-Nya QS.3: 103 yang inti kandungannya larangan bercerah berai atau segala hal yang menimbulkan perpecahan harus dihindiari.

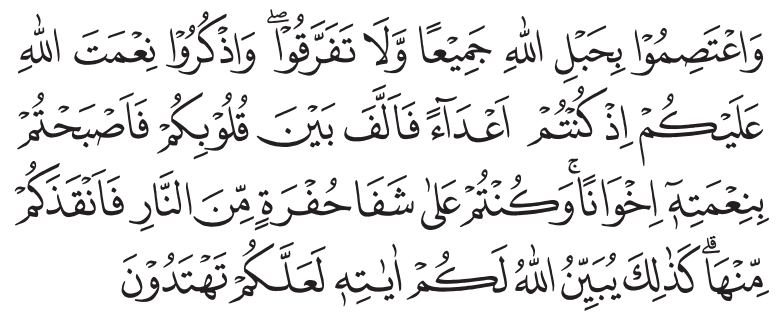

Dan berpeganglah kamu semuanya kepada tali (agama) Allah, dan janganlah kamu bercerai berai, dan ingatlah akan nikmat Allah kepadamu ketika kamu dahulu (masa Jahiliyah) bermusuh-musuhan, maka Allah mempersatukan hatimu, lalu menjadilah kamu karena nikmat Allah, orang-orang yang bersaudara; dan kamu telah berada di tepi jurang neraka, lalu Allah menyelamatkan kamu dari padanya. Demikianlah Allah menerangkan ayat-ayat-Nya kepadamu, agar kamu mendapat petunjuk.

Ayat ini menunjukkan perintah agar seluruh umat Islam berpegang teguh pada aturan Allah SWT, dan dilarang berecrai berai. Oleh karena itu, sekiranya bangsa Indonesia melakukan Pilkada sesuai dengan regulasi yang sudah ada tentang Pilkada, niscaya agenda demokrasi yang ada tidak akan kacau dan terjadi disintegrasi ummat. Menempatkan kebutuhan bangsa ini sesuai sumber hukum di Indonesia yaitu UUD ' 45 dan Pancasila.

Dalam Islam kepemimpinan bertugas sebagai pengganti dalam melindungi agama dan mengatur kemaslahatan hidup.Berdasarkan ijma' ulama bahwa

\footnotetext{
${ }^{20}$ Pembukaan UUD’45 alinea I
}

mengangkat seseorang yang memiliki kredibilitas dalam menjalankan tugas kepemimpinan di kalangan umat ini adalah wajib meskipun Imam al-asham ${ }^{21}$ tidak sependapat dengan mereka. ${ }^{22}$

Pilkada termasuk pranata sosial, karena didalamnya ada wadah yang mengatur sosial masyarakat, ada moral dan nilai yang akan mewadahi aspirasi masyarakat dalam menentukan pemimpinnya yang akan mengendalikan dan mengatur daerah dan masyarakatnya. Pilkada adalah sejatinya harus sesuai dengan aturan yang ada dalam Islam, sebagaimana Syûrâ yang sudah dijelaskan di atas.Sekalipun sistem politik Indonesia dalam Pilkada tidak menggunakan sistem Syûrâ, tapi dalam sistem demokrasi di dalamnya sudah ada Syûrâ.Sehingga hal ini tidak menutup kemungkinan untuk sesuai dengan aturan Islam secara kontennya. Demikian itu, dikarenakan bahwa ketika seseorang akan melakukan dan menentukan calon pemimpin atau kepala daerah di Indonesia, lobi-lobi politik atau Syûrâ itulah yang dikedepankan oleh para pemimpin dan partai-partai yang ada di Indonesia. Hanya saja dalam teori seakanakan mengedepankan sistem Syûrâ (teori Islam) tapi praktiknya, banyak yang menyalahi teori-teori tersebut (mengotori sistem Syûrâ), yaitu dengan kecurangan yang terjadi saat kampanye, misalkan dengan menggunakan money politic yang dilakukan oleh para kandidat kepala daerah untuk meraup suara yang banyak agar menang dan melakukan cara-cara keji lainnya.

Adapun Pilkada yang ada di Indonesia ini adalah, meliputi: (1) Pemilu Gubernur dan Wakil Gubernur; (2) Pemilu Bupati dan Wakil Bupati; (3) Pemilu Walikota dan Wakil Walikota.

Sebelumnya, kepala daerah dan wakil kepala daerah dipilih oleh Dewan Perwakilan Rakyat Daerah (DPRD). Dasar hukum penyelenggaraan pilkada adalah UndangUndang Nomor 32 Tahun 2004 tentang Pemerintahan Daerah. Dalam undang-undang ini, pilkada (pemilihan kepala daerah dan wakil kepala daerah) belum dimasukkan dalam rezim pemilihan umum (pemilu). Pilkada pertama kali diselenggarakan pada bulan Juni 2005.

Sejak berlakunya Undang-Undang Nomor 22 Tahun 2007 tentang Penyelenggara Pemilihan Umum, pilkada dimasukkan dalam rezim pemilu, sehingga secara resmi bernama "pemilihan umum kepala daerah dan wakil kepala daerah". Pilkada pertama yang diselenggarakan

${ }^{21}$ Nama lengkapnya adalah Abdurrahman Ibn Kaisan, Abu Bakar al-Asham (w. 225) Ia adalah seorang ahli fikih dari kalangan Mu'tazilah, juga seorang mufassir yang dikenal sangat wara' ia berada dipihak Muawiyah di dalam menentang kepemimpinan Ali ibn Abi Thalib ra.

${ }^{22}$ Imam al-Mawardi, al-Ahkam al-Sulthaniyyah,terjmhn: Sistem Pemerintahan Khilafah Islam, Pnrjmah: KHalifurrahman Fath dkk. (Jakarta: Qisthi Press, 2015), Cet. I, h. 10 
berdasarkan undang-undang ini adalah Pilkada DKI Jakarta $2007^{23}$.

Pilkada diselenggarakan oleh Komisi Pemilihan Umum (KPU) Provinsi dan KPU Kabupaten/Kota dengan diawasi oleh Panitia Pengawas Pemilihan Umum (Panwaslu) Provinsi dan Panwaslu Kabupaten/Kota.

Khusus di Nanggroe Aceh Darussalam, Pilkada diselenggarakan oleh Komisi Independen Pemilihan (KIP) dengan diawasi oleh Panitia Pengawas Pemilihan Aceh (Panwaslih Aceh). Khusus di Nanggroe Aceh Darussalam, peserta Pilkada juga dapat diusulkan oleh partai politik lokal.

Berdasarkan Undang-Undang Nomor 32 Tahun 2004, peserta pilkada adalah pasangan calon yang diusulkan oleh partai politik atau gabungan partai politik. Ketentuan ini diubah dengan Undang-Undang Nomor 12 Tahun 2008 yang menyatakan bahwa peserta pilkada juga dapat berasal dari pasangan calon perseorangan yang didukung oleh sejumlah orang. Undang-undang ini menindaklanjuti keputusan Mahkamah Konstitusi yang membatalkan beberapa pasal menyangkut peserta Pilkada dalam Undang-Undang Nomor 32Tahun 2004. ${ }^{24}$

\section{Dasar Hukum Pemerintahan Daerah}

Undang-Undang Dasar Negara RI tahun 1945 merupakan hukum tertinggi dan instrument utama bagi pemerintah Indonesia. UUD 1945 ini telah menuntut proses perubahan berbagai lembaga pemerintahan dan menjadi dasar bagi stabilitas politik, kebebasan hak asasi manusia, pertumbuhan ekonomi dan kemajuan social. Sejak berdirinya NKRI pada tanggal 17 Agustus 1945 dengan system desentralisasi-karena Negara merupakan suatu organisasi kekuasaan (kewibawaan) atau sebuah bentuk pergaulan hidup yang harus memenuhi persyaratan tertentu, antara lain: ada pemerintah yang berdaulat, wilayah (daerah) tertentu dan rakyat yang hidup teratur, yang merupakan syarat minimum yang harus dimiliki oleh tiap-tiap Negara serta harus ada tujuannya-para pendiri Negara telah menjatuhkan pilihannya pada prinsip pemencaran kekuasaan dalam penyelenggaraan pemerintahan Negara Indonesia yang tujuannya tercantum pada alinea keempat Pembukaan Undang-Undang Dasar 1945: “...melindungi segenap bangsa Indonesia dan seluruh tumpah darah Indonesia dan untuk memajukan kesejahteraan umum, mencerdaskan kehidupan bangsa, dan ikut melaksanakan ketertiban dunia yang

\footnotetext{
23 https://kpudaerah.wordpress.com/about/diunduh pukul 20 WIB, Mei 2015

${ }^{24}$ Pipin Syarifin dan Dedah Jubaedah "Pemerintahan Daerah di Indonesia” (Bandung:Pustaka Setia, 2005), h. 161.
}

berdasarkan kemerdekaan, perdamaian abadi dan keadilan sosial." Untuk mecapai maksud itu, para pejabat di daerah-daerah membantu mewujudkan penyelengaraan Pemerintah Daerah dan kesejahteraan sosial melalui pembangunan daerah, karena daerah Indonesia terbagi dalam daerah yang bersifat otonom atau bersifat daerah administrasi ${ }^{25}$.

Dalam kaitannya dengan pemilihan kepala daerah yang ada di Indonesia, terbukti sudah tidak sesuai dengan pranata sosial Islam.Mengapa demikian? Karena hanya beberapa daerah saja yang masyarakatnya sudah memiliki pendidikan politik tentang Pilkada kemudian dapat meraih suara yang signifikan tanpa kecurangan, dan tanpa diiming-imingi sesuatu, seperti hadiah dan uang (money politic). Karena terbukti bila tidak diberikan edukasi politik sebelumnya, maka partai yang memiliki power dan uang yang lebih besar akan mendominasi masyarakat sehingga ia menang. Ini yang seharusnya selalu dilakukan dan diantisipasi oleh para stake-holder pemerintahan daerah, yaitu dengan cara memberikan edukasi politik ke masyarakat tentang Pilkada secara dini, agar tidak mudah diimingi dengan janji dan uang yang hanya memenuhi kebutuhan sesaat, setelah itu mereka ditinggalkan.

Dalam sistem Pemerintahan Islam gambaran pengangkatan kepemimpinan yaitu, dapat dilakukan denga dua cara:pertama; pemilihan oleh ahlul aqdi wal hal; kedua penunjukkan oleh imam (khalifah) ${ }^{26}$. Untuk kasus Pilkada di Indonesia sepertinya berbeda karena di era 2005-sekarang, pemilihannya dengan caralangsung dipilih oleh rakyat. Model cara pemilihan seperti ini sebenarnya hampir sama dengan yang dicontohkan oleh para Sahabat Nabi ketika memilih Abu Bakr ra. menjadi khalifah pertama menggantikan Nabi SAW. Oleh karenanya Pilkada di Indonesia sebenarnya bisa dikatakan hampir sesuai dengan yang disyariatkan oleh Islam.Misalkan dengan sistem demokrasi, jika demokrasi yang dimaksud untuk kepentingan rakyat "dari rakyat oleh rakyat dan untuk rakyat" maka ini sesuai dengan Islam. Dalam kaidah fiqih dijelaskan bahwa المصلحة العامة artinya: "Kepentingan umum harus didabulukan daripada kepentingan pribadi”. ${ }^{27}$ Dalam praktik dilapangan, yang terjadi dengan bangsa ini bahwa demokrasi hanya dirasakan oleh mereka yang menjabat bukan mereka para rakyat, dalam sistem demokrasi yang seharusnya dari rakyat, oleh rakyat dan hasilnya pun untuk rakyat, karena sistem praktik kepemimpinan-

\footnotetext{
${ }^{25}$ Pipin Syarifin dan Dedah Jubaedah "Pemerintahan Daerah di Indonesia", h. 13.

${ }^{26}$ Imam al-Mawardi, al-Ahkam al-Sulthaniyyah, h. 12.

${ }^{27}$ Abu Ishak al-Syatibi, al-Muwafaqat fi Ushul al-Ahkam, (Daar al-Rasyad al-Haditsah, tt.), h. 243.
} 
nya yang salah maka rakyat yang terkena akibatnya. Sementara para pemimpin menari di atas penderitaan rakyatnya, sangat jauh berbeda dengan kepemimpinan para Khulafaurrasyidin dan para pemimpin Islam yang mereka memimpin sesuai dengan aturan Islam dan mengamalkan ajaran-Nya. Seperti yang dilakukan oleh cucunda atau keturunan Umar bin Khattab yaitu Umar bin Abdul Aziz, beliau tidak mau sedikitpun menggunakan uang Negara apalagi untuk keluarganya. Beliau selalu mengkhawatirkan akan keadaan rakyatnya, beliau takut kalau-kalau rakyatnya kelaparan akibat dari kebijakannya yang salah, beliau sangat takut uang Negara/ rakyat termakan oleh keluarganya. Sehingga pada suatu hari ketika anaknya berkunjung kepada beliau untuk suatu urusan, belaiu bertanya: "apakah masalah yang akan kau bicarakan ini menyangkut Negara/rakyat atau pribadi? Ketika anaknya menjawab urusan pribadi, maka beliau mematikan lentera sebagai penerang ruangan kerja beliau itu, dengan alasan lentera itu dinyalakan oleh minyak yang menggunakan uang Negara, maka tidak ada hak bagi anaknya atau keluarganya untuk menikmatinya. ${ }^{28}$

Demikian itu adalah sifat kehatia-hatian seorang muslim yang sejati, berakidah lurus dan benar sesuai dengan ajaran-Nya. Maka akan selalu memberikan manfaat bagi banyak orang, bukan merugikan ataupun menyengsarakannya. Dalam al-Quran gambaran manusia seperti itu adalah laksana seekor lebah yang tidak akan memakan makanan haram atau kotor, ia akan memilah dan memilih makanan yang benarbenar steril dari pengaruh-pengaruh negatif, yang akhir hasilnya akan dapat mmemudharatkan diri sendiri dan orang lain, tapi sebaliknya manusia beriman yang diumpamakan seperti lebih, hasil akhirnya dapat dimanfaatkan dan dirasakan oleh banyak orang, yaitu madu yang menjadi obat untuk semua orang tanpa pandang bangsa dan agama, semua orang bisa menggunakannya. Demikian manusia beriman yang akhir hasilnya bisa dimanfaatkan oleh banyak orang adalah ilmu dan akhlak yang dimilikinya, akan bermanfaat bagi orang lain yang ada disekitarnya.Apakah masih ada pemimpin negeri ini yang memiliki nurani sesuai dengan tuntunan Islam?Sebenarnya masih ada, tapi kemunculannya teramat lama dan mungkin masih terseok-seok dengan keadaan politik Indonesia yang kurang menguntungkan ini.Bagi orang-orang yang ingin bangkit menegakkan kebenaran seharusnya tetap istiqomah dan terus berjuang menyuarakan kebenaran sampai titik darah penghabisan.

${ }^{28}$ Disarikan dari bacaan penulis tentang sejarah Khalifah Umar bin Abd Aziz

\section{Penutup}

Syûrâ dan demokrasi yang dianut di Indonesia merupakan sistem perpolitikan yang sudah menjadi pranata sosial, yang mencakup di dalamnya norma/ nilai, aturan, dan institusi. Kemudian keduanya jika ditinjau dari pranata sosial Islam merupakan ajaran dan perintah ilahi, yang jika dijalankan dengan benar maka akan mendatangkan kemaslahatan untuk semua bangsa Indonesia.

Hanya saja bila dilihat dari keadaan sekarang ini, sepertinya bangsa ini sudah kehilangan pegangan dan aturan bahkan jati dirinya, terbukti mereka sudah mengkhianati kesucian dan keagungan makna musyawarah dan demokrasi, di mana terlihat para pejabat, anggota dewan dan para stakeholder negeri ini selalu bertengkar manakala mereka sedang bermusyawarah. Seakan-akan mereka sedang mencerminkan dan memperlihatkan kelemahannya di mata publik, bahwa mereka itu orangorang yang sombong, haus kekuasaan dan tidak memiliki etika dan lainnya.

Jika dilihat dan diperhatikan kembali ayat-ayat tentang Syûrâ, betapa Islam memuliakan umatnya dengan memerintahkan Syûrâ, agar mereka saling menghargai satu dan lainnya, dan menyatukan langkah untuk kemaslahatan bersama. Tapi itu semua hanya sekadar isapan jempol dan pemanis belaka, tidak dijadikan sebagai rujukan dan patokan dalam kehidupannya yang kemudian mereka tak pernah bersyukur dengan anugerah yang diberikan kepadanya. Padahal, ilmu yang bermanfaat itu tidak harus banyak, sedikit tapi diamalkan dalam kehidupannya demi kebahagiaan dunia dan akhirat.[]

\section{Pustaka Acuan}

Al-Quran dan Terjemahan Kementerian Agama RI

Ali al-Shabunî, Muhammad, Shafwah al-Tafâsîr, Beirut: Dâr al-Qalam, t.th. , Mukhtashar Tafsir Ibn Katsîr, Beirut: Dâr alFikr, t.th.

Dhiauddin Rais, Muhammad, Al-Nazhariyyât alSiyâsah al-Islâmiyyah, terjemahan: Teori Politik Islam, Penerjemah Abd Hayyie al-Kattalni dkk., Jakarta: Gema Insani Press.

Ibn Taymiyah, Siyâsah Syarizyah, terjemahan: Etika Politik Islam, Surabaya: Risalah Gusti, 2005.

Mawardi, al-, al-Ahkâm al-Sulthâniyyah, terjemahan: Sistem Pemerintahan Khilafah Islam, Penerjemah: Khalifurrahman Fath dkk., Jakarta: Qisthi Press, 2015.

Munawwir, Ahmad Warson, Al-Munawwir: Kamus Arab-Indonesia, Surabaya: Pustaka Progreesif, 1997.

Ibn Hisyam, Sirah Nabawiyyah Ibn Hisyâm, penerjemah 
Fadhli Bahri, Jakarta: Dâr al-Falâh, 2005.

Jâzirî, al-, 'Abd al-Rahman, Al-Fiqh 'Alâ al-Madzâhib al-Arba'ah, Beirut: Dâr al-Fikr, t.th.

Muhammad al-Syâwî, Tawfiq, Fiqh al-Syûrâ wa alIstisyârah, Terjemehan: Demokrasi atau Syûrâ, Penerjemah: Djamaluddin Z.S., Jakarta: Gema Insani, 2013.

Qarâdhawî, al-, Yûsuf, Malâmih al-Mujtama' al-Muslim, terjemahan: Masyarakat Berbasis Syariat Islam, Solo: Era Adicitra Intermedia, 2013.

, Fiqih Negara, Jakarta: Rabbani Press, 1997.

Raghib, al-, al-Ashfahanî, Mufradât Alfâzh al-Qur'ân", Beirut: al-Maktabah al-Assrya, t.th.

Shihab, Muhammad Quraish, Wawasan al-Qur'an:
Tafsir Tematik atas Berbagai Persoalan Umat, Jakarta: Mizan, 2007.

Syarifin, Pipin dan Jubaedah, Dedah, Pemerintahan Daerah di Indonesia, Bandung: Pustaka Setia, 2005. Syâthibî, al-, Abû Ishâq, al-Muwâfaqât fi Ushûl alAhkâm, Dâr al-Rasyâd al-Hadîtsah, t.th.

Zuhaylî, al-, Wahbah, Tafsir al-Munîr:'Aqîdah, Syarî'ah, Manhaj, Penerjemah: Abdul Hayyie al-Kattani, dkk, Jakarta: Gema Insani, 2013.

\section{Website}

http://muslim.or.id/manhaj/Syûrâ-dalam-pandanganislam-dan-demokrasi.html.

https://kpudaerah.wordpress.com/about/ 